\title{
Green chitosan: thiourea dioxide cleaning gel for manganese stains on granite and glass substrates
}

\author{
Bruno Campos ${ }^{1,2}$, Alexandra Marco 1,2, Guilhermina Cadeco ${ }^{3}$, David M. Freire-Lista ${ }^{4,5}$, Joaquin Silvestre-Albero ${ }^{6}$, \\ Manuel Algarra ${ }^{7}$, Eduarda Vieira' ${ }^{1}$, Manuela Pintado ${ }^{2}$ and Patrícia Moreira ${ }^{1,2^{*}}$ (D)
}

\begin{abstract}
The cleaning or removal of manganese stains on Cultural Heritage has not been much tested or successful so far. The aim of this article was to assess a new green cleaning gel for Mn-rich black-blue stains on different substrates. The black-blue stains were characterized at optical and chemical level through colour-related data, optical microscope, FTIR, XRF and XPS. Mn-stained granite found on historical churches at Vila Real (North of Portugal) and glass jars of Leclanché cells, belonging to the ISEP's Museum (Portugal) collection, were the ideal case studies to test the efficiency of chitosan: thiourea dioxide (TD) cleaning gel. TD proved to be the best candidate to reduce insoluble manganese oxides, over Hydroxylamine Hydrochloride and Hydroxymethanesulfinic Acid. Cleaning assays performed on stained granite samples collected at a historical quarry and in situ application on stained granite churches allowed removal of the stains to a satisfactory level. Similar results were obtained on stained glass jars.
\end{abstract}

Keywords: Manganese stains, Granite, Glass, Leclanché cells, Green cleaning gel, Chitosan

\section{Introduction}

Manganese staining involving built heritage and cultural artefacts is a rare occurrence that has been recently reported, mainly in underground sites, like caves and historical buildings. For instance, the cases of Neang Khmau temple-Cambodia (laterite) [1], Freiburger Münster-Germany (sandstone) [2], Smithsonian Institute-Washington D.C. (red seneca sandstone) [3], Paranhos spring water tunnel-Portugal (granite) [4] or the caves of LauscaxFrance (sandstone) [5] and Pautler-Southwest Illinois (limestone) [6]. Some articles describe this type of staining as a rock varnish defined by a thin dark Mn-enriched coating on rock surfaces. The thickness of this coating could range from 10 to $1 \mathrm{~mm}$ and the $\mathrm{Mn}$ percentage from 2 to $45 \mathrm{wt} \%$, approximately [7].

\footnotetext{
*Correspondence: prmoreira@ucp.pt

${ }^{1}$ Research Centre for Science and Technology of the Arts, Universidade

Católica Portuguesa, Porto, Portugal

Full list of author information is available at the end of the article
}

The phenomenon associated to this type of stains is still unclear. Notwithstanding, two hypotheses are associated to them. One, indicating the leaching and redeposition of $\mathrm{Mn}$ aerosol at the surface, from airborne dust grains, followed by autocatalytic oxidation $[8,9]$. A second, indicating the efflorescence and precipitation phenomenon, where the Mn source is assigned to the diffusion of soluble $\mathrm{Mn}$ through the rocks, originated from enriched $\mathrm{Mn}$ rocks, soils or groundwater [10,11]. The formation of Mn-rich coatings occurs through the oxidation of soluble $\mathrm{Mn}^{2+/ 3+}$ to insoluble $\mathrm{Mn}^{4+}$, like $\mathrm{MnO}_{2}$, and inherent to this process, it can be ensued by autocatalysis and/or biogenic oxidation [12-19]. Regarding cultural artefacts, a type of Mn-staining in Leclanché cells is reported on glass cell jar.

Currently, the solutions to remove this type of stains is non-existent. Nevertheless, an unfeasible solution can be found to remove manganese oxides from laterite rock samples, immerging them into an oxalic acid solution. This strategy discloses some problems inherent to the
Springer Open

(c) The Author(s) 2021. Open Access This article is licensed under a Creative Commons Attribution 4.0 International License, which permits use, sharing, adaptation, distribution and reproduction in any medium or format, as long as you give appropriate credit to the original author(s) and the source, provide a link to the Creative Commons licence, and indicate if changes were made. The images or other third party material in this article are included in the article's Creative Commons licence, unless indicated otherwise in a credit line to the material. If material is not included in the article's Creative Commons licence and your intended use is not permitted by statutory regulation or exceeds the permitted use, you will need to obtain permission directly from the copyright holder. To view a copy of this licence, visit http://creativecommons.org/licenses/by/4.0/. The Creative Commons Public Domain Dedication waiver (http://creativeco mmons.org/publicdomain/zero/1.0/) applies to the data made available in this article, unless otherwise stated in a credit line to the data. 
toxicity of oxalic acid, the high diffusion of aqueous solvents into porous stones and the destructive behaviour of this method [10]. Due to these problems, that solution is not suited for application on heritage granite and glass, both porous materials and a new solution with lower toxicity and presenting more control over the diffusion of the solvents was needed.

This article presents an innovative, feasible and green chitosan gel embedded with thiourea dioxide and phosphoric acid, applied in the cleaning of Mn-stained granite and glass found on historical churches, placed at Vila Real (North of Portugal), and inside the glass jar of Leclanché cells.

The main goal of this work was to evaluate the potential and effectiveness of cleaning gel solutions on two manganese-stained subtracts in order to propose conservation-restoration procedures in Cultural Heritage context. To evaluate the results of the three different gels, several Romanesque granite churches in Vila Real district were chosen due to their type of Mn-rich black-blue stains on granite blocks and even on frescoes, as well as a stained-glass jar of Leclanché cells, property of the ISEP Museum-Porto (Portugal).

\section{Methods}

\section{Case studies}

Vila Marim Church (Fig. 1A1 and A2) was built on the twelfth century and the inner walls of the chancel and nave are partially decorated with frescoes, showing different campaigns. The oldest campaign from the fifteenth century is located on the nave, on the gospel side, observed between the lacunae of the second, sixteenth century, campaign. On the chancel, there are also two campaigns but from different guilds, the first of the fifteenth century and the latter from the sixteenth century with a cartouche bearing the date 1549 and attributed to the painter Arnaus F. [20].

Folhadela Church (Fig. 1B1 and B2) is a temple from the thirteenth century with profuse alterations during the eighteenth century. The remaining mural paintings survived by being concealed behind baroque altars. They are distributed by the lateral (left and right) walls and top of the triumphal arch as well as the main chapel overall bottom wall and fragments at its lateral walls. The fragments on the upper part of the triumphal arch's lateral walls and the lower left wall area have similarities to Arnaus F. craftsmanship operating in this region between 1535 and 1549 and also, the painting on top of the triumphal arch, although afterwards repainted. The bottom of the triumphal right wall is from a later hand, around the second half of the sixteenth century. The bottom wall on the main chapel presents at least three different campaigns from 15 and sixteenth centuries [21].
Mouçós Church (Fig. 1C1 and C2) was built at the beginning of the sixteenth century along with its remaining mural painting at the main chapel and altar table, dated from 1529 as a legend conveys [22]. Granite slabs from the historical quarries of the case studies described were used for cleaning tests as described next.

Leclanché cell (Fig. 2) was invented by the french scientist, Georges Leclanché in 1868. It is considered a single-fluid cell because it is composed by a square shaped glass jar with a saturated aqueous solution of ammonium chloride (electrolyte), a zinc bar (anode) and a porous pot (cathode), dipping into it but not touching. The porous pot is filled with a mixture of pulverized carbon and black oxide of manganese and a carbon bar inside $[23,24]$. The electric current of this cell is generated by a chemical reaction in which $\mathrm{Mn}$ (IV) is reduced to $\mathrm{Mn}$ (III) at the cathode and $\mathrm{Zn}(0)$ is oxidized to $\mathrm{Zn}$ (II) at the anode [25], producing a net cell potential $\left(\Delta E_{e l}\right)$ of $1.4 \mathrm{~V}$, roughly (1).

$$
\begin{aligned}
& \mathrm{Zn}(s)+2 \mathrm{MnO}_{2}(s)+2\left(\mathrm{NH}_{4}\right) \mathrm{Cl}(a q) \\
& \quad+2 \mathrm{H}_{2} \mathrm{O}(l) \rightarrow \mathrm{ZnCl} l_{2}(a q)+2 \mathrm{Mn}(\mathrm{OH})_{3} \\
& \quad+2 \mathrm{NH}_{3}(a q)+\Delta E_{e l}
\end{aligned}
$$

\section{Cleaning assays}

The formulation of a gel able to clean unaesthetically Mn-rich stains was based on four main requirements: (i) a renewable biopolymer able to impart a gel like-behaviour to delay the evaporation of embedded solvents, prolonging their action, improving the contact between the solution gel and the substrate, reducing, concomitantly, the penetration of the solvent inside the substrate; (ii) the acidity of the media. The solubility of insoluble oxide metals, like $\mathrm{MnO}_{2}$, is facilitated in $\mathrm{pH}$ under 7.0 , at $25^{\circ} \mathrm{C}$ (as can be proved by Pourbaix diagrams); (iii) the mandatory use of a reductant to promote the reduction of insoluble Mn (IV) to soluble Mn (II/III); (iv) all the previous parameters should respect one of the Green Chemistry principles, using safer, natural and eco-friendly materials mainly based on renewable feedstocks, generating minimal or innocuous waste whenever possible.

The products chosen to fulfil the previous requisites are $1 \%(\mathrm{w} / \mathrm{v})$ of chitosan (dissolved in $1 \%(\mathrm{v} / \mathrm{v})$ of glacial acetic acid) and phosphoric acid, being these constant parameters. The reductants chosen to promote the reduction of insoluble Mn (IV) to soluble Mn (II/III) were Thiourea Dioxide (TD), Hydroxylamine Hydrochloride $(\mathrm{HH})$ and Hydroxymethanesulfinic Acid (HSA), in function of the time and at room temperature. Aqueous solutions of TD, HH and HSA, were prepared separately, with a concentration of $40 \mathrm{mM}$, in a volume of $30 \mathrm{~mL}$ of 

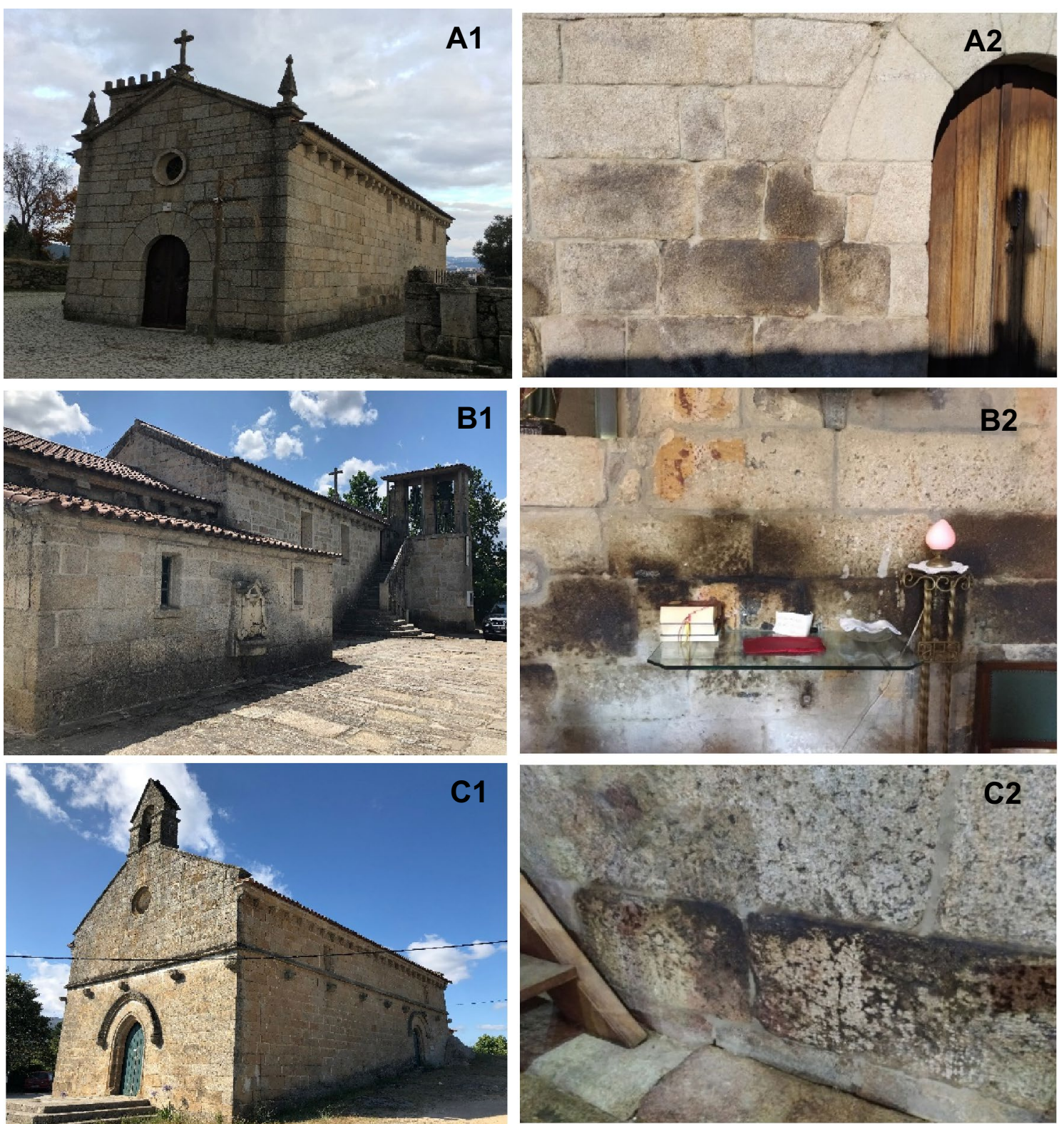

Fig. 1 Outside overview and respective black-blue stains at Sta. Marinha (A1 and A2), St. Tiago (B1 and B2) and N.S. Guadalupe churches (C1 and C2)

deionised water, containing $10 \mathrm{mg}$ of dispersed $\mathrm{MnO}_{2}$, under stirring. Within a period of $75 \mathrm{~min}, 500 \mu \mathrm{L}$ of each solution was removed every $15 \mathrm{~min}$, in three replicas. It was then centrifuged to separate the supernatant from the insoluble $\mathrm{MnO}_{2}$, diluted to $15 \mathrm{~mL}$ with a nitric acid solution $(0.1 \mathrm{M})$ and, finally, the soluble manganese was quantified by AAS. These procedures were replicated three times.

The green gel used to clean Mn-rich stains on granite and glass substrates was prepared weighing $20 \mathrm{~g}$ of chitosan $(6 \% \mathrm{w} / \mathrm{v}$, high molecular weight) solution in Acetic Acid (1\% v/v), adding later $5 \mathrm{~mL}$ of deionised water and $5 \mathrm{~mL}$ of Phosphoric Acid ( 85 wt. \% in $\mathrm{H}_{2} \mathrm{O}$ ), manually stirring until obtaining a homogeneous gel. After the confection of chitosan gel, a thiourea dioxide aqueous solution was prepared dissolving $1 \mathrm{~g}$ of TD in $20 \mathrm{~mL}$ of deionised water at $50^{\circ} \mathrm{C}$, under stirring, enabling the dissolution process. Finally, chitosan gel and TD solution were manually mixed and stirred until obtaining a uniform gel. 


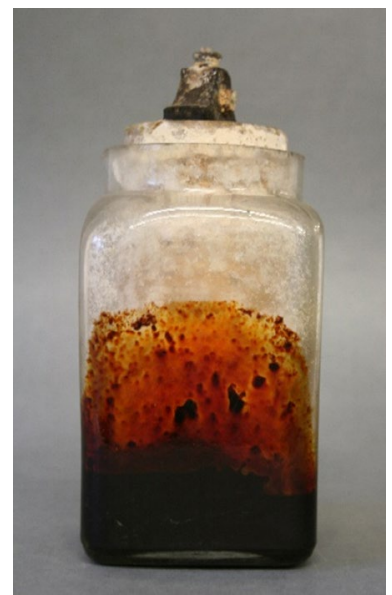

Fig. 2 Current conservation state of a Leclanché cell, belonging to ISEP Museum-Porto (Portugal)

The cleaning gel used to test on different stained substrates was freshly prepared and the assays respected the following order: (i) granite samples collected from historical quarries; (ii) in situ application on manganese-stained granite churches; and (iii) manganesestained glass of Leclanché cells.

Mn-stained granite samples were collected at an historical granite quarry placed at Vila Real district, in which, a stained area was selected for surface application of the cleaning gel and left to act for $2 \mathrm{~min}$. It was then gently wiped with cotton swabs, performing circular movements for $1 \mathrm{~min}$. Finally, the gel was removed, spraying the surface with deionised water. Residues were rinsed with absorbent kraft paper. Tests performed in situ on stained granite ashlars at Sta. Marinha, S. Tiago and N.S. Guadalupe churches followed identical procedures as described on granite samples.

Cleaning tests performed on Mn-stained Leclanché cells, followed the same procedures described above.

\section{Analytical methodology RGB data}

Cleaning effectiveness of the gel on the stained-glass cell jar was assessed through the analysis of photographs taken before and after gel application. A Canon 5D Mark II camera was used to register the process with the following settings: ISO 640; $50 \mathrm{~mm}$ lens; F/2,8; $1 / 100 \mathrm{~s}$; White Balance of $3650^{\circ} \mathrm{K}$ and a TINT $28+$. Two points were chosen in each glass jar to verify the before and after RGB data. It was used a white sheet inside the glass jar to isolate the face behind. The glass itself is not totally transparent but when comparing the results of the same dots of the paper sheet is clear the differences between before and after cleaning process.

\section{Optical microscope (OM)}

Microscopic analysis of the stained granite was performed and recorded with the portable OM Dino-lite Pro2 AD 4000 series, using magnifications of $50 \times$ and $430 \times$.

\section{Colorimetry}

The colorimetric data of black-blue stains were measured using the Chroma Meter CR-400, made by Konica Minolta, equipped with a standard colorimetric observer $\left(2^{\circ}\right)$ and a standard illuminant (C\&D65), according to equipment instructions. The size of measurement aperture is $\varnothing 8 \mathrm{~mm}$. After a soft cleaning with a brush, three measurements were performed at each sampling site, pressing the equipment against the selected area of analysis, avoiding the interference of external light. The results were evaluated by CIELAB colour system, defined by the International Commission on Illumination (CIE) in 1976 (http://cie.co.at). The measured chromatic coordinates were $\mathrm{L}^{*}, \mathrm{a}^{*}$ and $\mathrm{b}^{*}$, corresponding to the lightness, red/ green axes and yellow/blue axes, respectively, as is standard with the use of these commercial colorimeters.

\section{Fourier-transform infrared spectroscopy (FTIR)}

FTIR was used to determine the functional groups corresponding to each vibrational frequency. The infrared spectra in transmission mode were recorded in the $4000-400 \mathrm{~cm}^{-1}$ frequency region using a Bruker Tensor 27 spectrometer. The measurements of the transmission bands were made using OPUS software supplied by the Bruker instrument. The pellet disks of $1.5 \mathrm{~cm}$ diameter were prepared by mixing $1 \mathrm{mg}$ sample with $200 \mathrm{mg} \mathrm{KBr}$ (Aldrich) and pressing at $10 \mathrm{~kg} / \mathrm{cm}^{2}$.

\section{Portable X-ray fluorescence ( $p X R F)$}

Elemental analyses of the patina were performed using a pXRF device conducted with a Thermo Scientific Niton XL3t-900 GOLDD (Geometrically Optimized large Drift Detector) analyser equipped with a silver (Ag) target and a $25 \mathrm{~mm}^{2}$ Silicon Drift Detector (SDD) with a resolution of $145 \mathrm{eV}$. The areas of interest were pinpointed using the integrated colour CCD camera and the integrated $3 \mathrm{~mm}$ small-spot collimation. The analyses were performed in triplicate using the mining mode with a total time of analysis settled at $180 \mathrm{~s}$, putting the pXRF nozzle directly on the surface of the stain. The semi-quantification of the elements was obtained through deconvolution of X-ray spectra using the WinAxil software. 


\section{$X$-ray Photoelectron Spectroscopy (XPS)}

XPS enables the determination of the surface chemistry until a near-surface region $(\sim 10 \mathrm{~nm}$ in depth). Providing the chemical bonding at surfaces/interfaces, a quantitative information and the electronic state of these elements allows the identification of their oxidation condition.

The spectra were recorded using a Physical Electronics PHI 5701 spectrometer with a non-monochromatic $\mathrm{Al} \mathrm{K} \alpha$ radiation $(300 \mathrm{~W}, 15 \mathrm{kV}, h v=1486.6 \mathrm{eV})$ as the excitation source. Spectra were recorded at $45^{\circ}$ take-off angle by a concentric hemispherical analyser operating in the constant pass energy mode at $25.9 \mathrm{eV}$, using a $720 \mathrm{~mm}$ diameter analysis area. Under these conditions the $\mathrm{Au} 4 f_{7 / 2}$ line was recorded with $1.16 \mathrm{eV} \mathrm{FWHM}$ at a binding energy of $84.0 \mathrm{eV}$. The spectrometer energy scale was calibrated using $\mathrm{Cu} 2 p_{3 / 2}, \mathrm{Ag} 3 d_{5 / 2}$ and $\mathrm{Au} 4 f_{7 / 2}$ photoelectron lines at 932.7, 368.3 and $84.0 \mathrm{eV}$, respectively. Charge referencing was done against adventitious carbon (C 1 s $284.8 \mathrm{eV})$. Samples were mounted on a sample holder without adhesive tape and kept overnight in high vacuum in the preparation chamber before being transferred to the analysis chamber of the spectrometer. Each region was scanned with several sweeps until a good signal to noise ratio was observed. The pressure in the analysis chamber was maintained lower than $10^{-9}$ Torr. A PHI ACCESS ESCA-V6.0 F software package was used for acquisition and data analysis. A Shirley-type background was subtracted from the signals. Recorded spectra were always fitted using Gauss-Lorentz curves in order to determine more accurately the binding energy of the different element core levels. The accuracy of binding energy (BE's) values was within $\pm 0.1 \mathrm{eV}$.

\section{Atomic Absorption Spectroscopy (AAS)}

The determination of soluble manganese was achieved by AAS with a Manganese (Mn) Lumina Hollow Cathode Lamp. $15 \mathrm{~mL}$ of $\mathrm{HNO}_{3}(0.1 \mathrm{M})$ was diluted and acidified in $500 \mu \mathrm{L}$ of each sample. The manganese stock solutions were prepared by diluting different aliquots of a $1000 \mu \mathrm{g} /$ $\mathrm{mL}$ manganese standard stock solution. The measurements were performed in a concentration range of $0.5-4 \mathrm{mg} / \mathrm{L}$ for the calibration curve with a linear regression of 0.9962 .

\section{Results and discussion}

The identification of the stains on the Leclanché glass jar was previously achieved by Cadeco et al. [26], which verified the presence of manganese dioxide on the stained glass. XRF analyses demonstrated that manganese was the most abundant element ( $25 \%)$ and XPS confirmed the presence of $\mathrm{MnO}_{2}$.

The chemical characterization of black-blue stains on granite at Santa Marinha, São Tiago and N. Sra. of Guadalupe churches were attained through XRF, FTIR and XPS analysis, demonstrated by the results reported hereinafter.

\section{Characterization of black-blue stains in Vila Real churches (north of Portugal)}

Unusual Mn-rich black-blue stains have been causing aesthetical changes on granite walls of Vila Real churches. These black-blue stains are mainly visible on granite support at all churches and in some areas of their frescoes. After an exhaustive searching of churches with Mn-rich stains, were found a typology of black-blue stains at Sta. Marinha (Vila Marim), St. Tiago (Folhadela) and Nossa Senhora de Guadalupe (Mouçós) churches, all located in Vila Real district (Additional file 1: Fig. SI1).

Table 1 shows the similarity between Mn-rich stains found in three churches of Vila Real. These black-blue stains are also characterized by the presence of iron because its chemical similarity with manganese.

In terms of elemental percentage, stained granite presents a manganese percentage 17.25 to 23.35 times higher than the unstained granite and the levels of iron are almost identical, resulting in $\mathrm{Mn} / \mathrm{Fe}$ ratios of $0.08 \pm 0.02$ and $1.64 \pm 0.57$ for unstained and stained

Table 1 Iron and Manganese percentage of black-blue stains on granite and CIELab color coordinates

\begin{tabular}{|c|c|c|c|c|c|c|c|c|}
\hline \multirow[t]{2}{*}{ Churches } & \multirow[t]{2}{*}{ Granite } & \multicolumn{4}{|c|}{ Elemental Analysis } & \multicolumn{3}{|c|}{ CIELab coordinates } \\
\hline & & $\mathrm{Fe}(\%)$ & $\mathrm{Fe}_{\mathrm{st}} / \mathrm{Fe}_{\mathrm{un}}$ & Mn (\%) & $\mathrm{Mn}_{\mathrm{st}} / \mathrm{Mn}_{\mathrm{un}}$ & $L^{*}$ & $a^{*}$ & $\mathbf{b}^{*}$ \\
\hline \multirow[t]{2}{*}{ Sta. Marinha } & Un & $1.01 \pm 0.19$ & 0.96 & $0.08 \pm 0.02$ & 18.73 & & & \\
\hline & St & $0.97 \pm 0.11$ & & $1.50 \pm 0.77$ & & $23.86 \pm 1.03$ & $3.36 \pm 0.34$ & $3.90 \pm 1.20$ \\
\hline \multirow[t]{2}{*}{ St. Tiago } & Un & $0.72 \pm 0.21$ & 0.85 & $0.08 \pm 0.04$ & 17.25 & & & \\
\hline & St & $0.61 \pm 0.30$ & & $1.38 \pm 0.53$ & & $21.16 \pm 1.39$ & $3.48 \pm 0.47$ & $3.07 \pm 0.37$ \\
\hline \multirow[t]{2}{*}{ N.S. Guadalupe } & Un & $0.79 \pm 0.31$ & 1.31 & $0.05 \pm 0.03$ & 23.35 & & & \\
\hline & St & $1.04 \pm 0.20$ & & $1.17 \pm 0.11$ & & $24.04 \pm 2.40$ & $3.59 \pm 0.74$ & $4.15 \pm 1.98$ \\
\hline
\end{tabular}

Un unstained; St stained, $L^{*}$ lightness; $a^{*}$ red/green component, $b^{*}$ yellow/blue component 
granite, respectively. Concerning to colorimetric characterization, the lightness measured for these stains was between $21.16 \pm 1.39$ and $24.04 \pm 1.39$ which agrees with the visual evaluation that revealed an apparent brightness (common in biofilms). The parameters $\mathrm{a}^{*}$ and $\mathrm{b}^{*}$ presented values between $3.36 \pm 0.34$ and $3.59 \pm 0.74$ for $\mathrm{a}^{*}$ component and between $3.07 \pm 0.37$ and $4.15 \pm 1.98$. These low positive values for $\mathrm{a}^{*}$ and $\mathrm{b}^{*}$ components result in a dark grey colour similar to what is visible with naked eye observation and with the RBG data from photography analysis. Also, very small differences between the churches case studies were detected for all components which is in accordance with our idea that the studied stains are similar in colour and a similar removal approach can be applied.

Were performed analytical techniques at Sta. Marinha, St. Tiago and N.S. Guadalupe churches to unveil the chemical composition of these type of stains on granite. Black-blue stains were analysed by FTIR (Additional file 1: Fig. SI2) and is observed the presence of symmetric and asymmetric stretching vibrations of $\mathrm{vCH}_{3}$ and $v \mathrm{CH}_{2}$ between 2920 and $2850 \mathrm{~cm}^{-1}$, and the stretching vibration of $v \mathrm{OH}$ at $3433 \pm 5 \mathrm{~cm}^{-1}$. The bands at 2360, 2337 and $1385 \mathrm{~cm}^{-1}$ are due to the absorption of atmospheric $\mathrm{CO}_{2}$. The range of bands between 1100 and $670 \mathrm{~cm}^{-1}$ may be ascribed to silicate vibrations (e.g. quartz, typically present on granite). The assignments between 528 and $420 \mathrm{~cm}^{-1}$ suggest the presence of Mn oxides, equivalent to $\mathrm{Mn}$ oxide coatings found on Lascaux cave (520, 470 and $420 \mathrm{~cm}^{-1}$ ) [5] and Paranhos spring water tunnel (529, 468 and $\left.425 \mathrm{~cm}^{-1}\right)$ [4].

These stains were also analysed with XPS on samples of the three churches (Additional file 1: Fig. SI3 and Table SI1). The binding energies at $532.40\left(\mathrm{O}_{1 \mathrm{~s}}\right)$ (Additional file 1: Fig. SI3e), $102.92\left(\mathrm{Si}_{2 \mathrm{p} 3}\right)$ (Additional file 1: Fig. SI3g) and $74.38 \mathrm{eV}\left(\mathrm{Al}_{2 \mathrm{p} 3}\right)$ (Additional file 1: Fig. SI3h) indicate the presence of silicates and aluminosilicates, concordant assignments with the granite substrate. The presence of organic elements is also shown at $284.55\left(\mathrm{C}_{1 \mathrm{~s}}\right)$ (Additional file 1: Fig. SI3d) and $406.90 \mathrm{eV}\left(\mathrm{N}_{1 \mathrm{~s}}\right)$ (Additional file 1: Fig. SI3f), corresponding to adventitious carbon and nitrates, respectively. The presence of halite $(\mathrm{NaCl})$ at $1071.35 \mathrm{eV}\left(\mathrm{Na}_{1 \mathrm{~s}}\right)$ (Additional file 1: Fig. SI3j) might be an evidence of the migration of some ions from groundwater, passing through the porous granite, and precipitating at the surface. The existence of manganese oxides in black-blue stains could be proved at 641.24 and $643.88 \mathrm{eV}$ (Additional file 1: Fig. SI3b), both assigned to $\mathrm{Mn}$ (II/ III) (e.g. $\mathrm{Mn}_{3} \mathrm{O}_{4}$ ) and $\mathrm{Mn}$ (IV) (e.g. $\mathrm{MnO}_{2}$ ), respectively. The same occurs for iron oxides at 709.52 and $712.45 \mathrm{eV}$ (Additional file 1: Fig. SI3c) attributed to Fe (II/III) (e.g. $\mathrm{Fe}_{3} \mathrm{O}_{4}$ ) and $\mathrm{Fe}$ (III) (e.g. $\mathrm{Fe}_{2} \mathrm{O}_{3}$ ), respectively. The spectral interpretation for samples collected at $\mathrm{S}$. Tiago and
N.S. Guadalupe is similar and is summarized in Additional file 1: Table SI1. It is also observed the presence of calcite, confirmed by the spin-dublet of $\mathrm{Ca} 2 p$ region at $347.13\left(\mathrm{Ca} 2 p_{1 / 2}\right)$ and $350.65 \mathrm{eV}\left(\mathrm{Ca} 2 p_{3 / 2}\right)$, giving a chemical shift of $\Delta \mathrm{Ca} 2 p \sim 3.5 \mathrm{eV}$ and an intensity peak ratio approximately $2: 1$, respectively (Additional file 1 : Fig. SI3i) [27]. The presence of calcite might indicate that some granite ashlars evaluated might have been whitewashed with lime, probably covered with frescoes since in all the churches studied present several sets of frescoes.

\section{Cleaning assays \\ Selection of reductant with best performance}

This study intended to ascertain the suitable reactant able to reduce insoluble $\mathrm{Mn}$ oxides $\left(\mathrm{Mn}^{4+}\right)$ to soluble manganese oxidation states $\left(\mathrm{Mn}^{2+/ 3+}\right)$. For these aim, Thiourea Dioxide (TD) [28], Hydroxylamine Hydrochloride (HH) [29], and Hydroxymethanesulfinic Acid (HSA) [30] were assayed.

The results obtained by AAS showed that TD and $\mathrm{HH}$ are the most effective $\mathrm{Mn}^{4+}$ reducing agents (Additional file 1: Fig. SI4). During the first $15 \mathrm{~min}$, approximately $80 \%$ of $\mathrm{Mn}^{4+}$ was reduced by TD and similarly $90 \%$ by $\mathrm{HH} . \mathrm{Mn}^{4+}$ was almost completely $(100 \%)$ reduced at 75 and 60 min by TD and $\mathrm{HH}$, respectively. TD and $\mathrm{HH}$ were thus selected as the best candidates to be used in the cleaning of Mn-rich stains. Inversely, HSA showed a weak reductive capacity, reaching only $10 \%$ after $75 \mathrm{~min}$, thus not being selected for the next steps.

\section{Application of chitosan: TD gel on different Mn-stained substrates}

The previous analysis showed that $\mathrm{TD}$ and $\mathrm{HH}$ are effective in the reduction of $\mathrm{Mn}^{4+}$ to soluble $\mathrm{Mn}^{2+/ 3+}$. Nevertheless, $\mathrm{HH}$ is known by its acute toxicity and carcinogenicity [29], inversely to TD that is considered a green reducing agent [28].

The optimal gel preparation was previously described and the main premise for its formulation is the use of green products, namely, the chitosan [31], acetic acid [32], phosphoric acid and thiourea dioxide [33]. The proposed green gel was applied on different $\mathrm{Mn}$-stained substrates to test its cleaning efficiency. Photos were taken before and after gel application on a stained face and two points were selected to get RGB data (1-8 points) using a Photoshop software. The same procedure was done with a white paper sheet and its RGB parameters (I-IV points) were setting as a cleaned material.

\section{Application on stained granite samples}

Cleaning efficiency of green gel was assayed, applying it on three different granite samples (Fig. 3 and Additional file 1: Fig. SI5). The black stains (marked yellow in Fig. 3) 


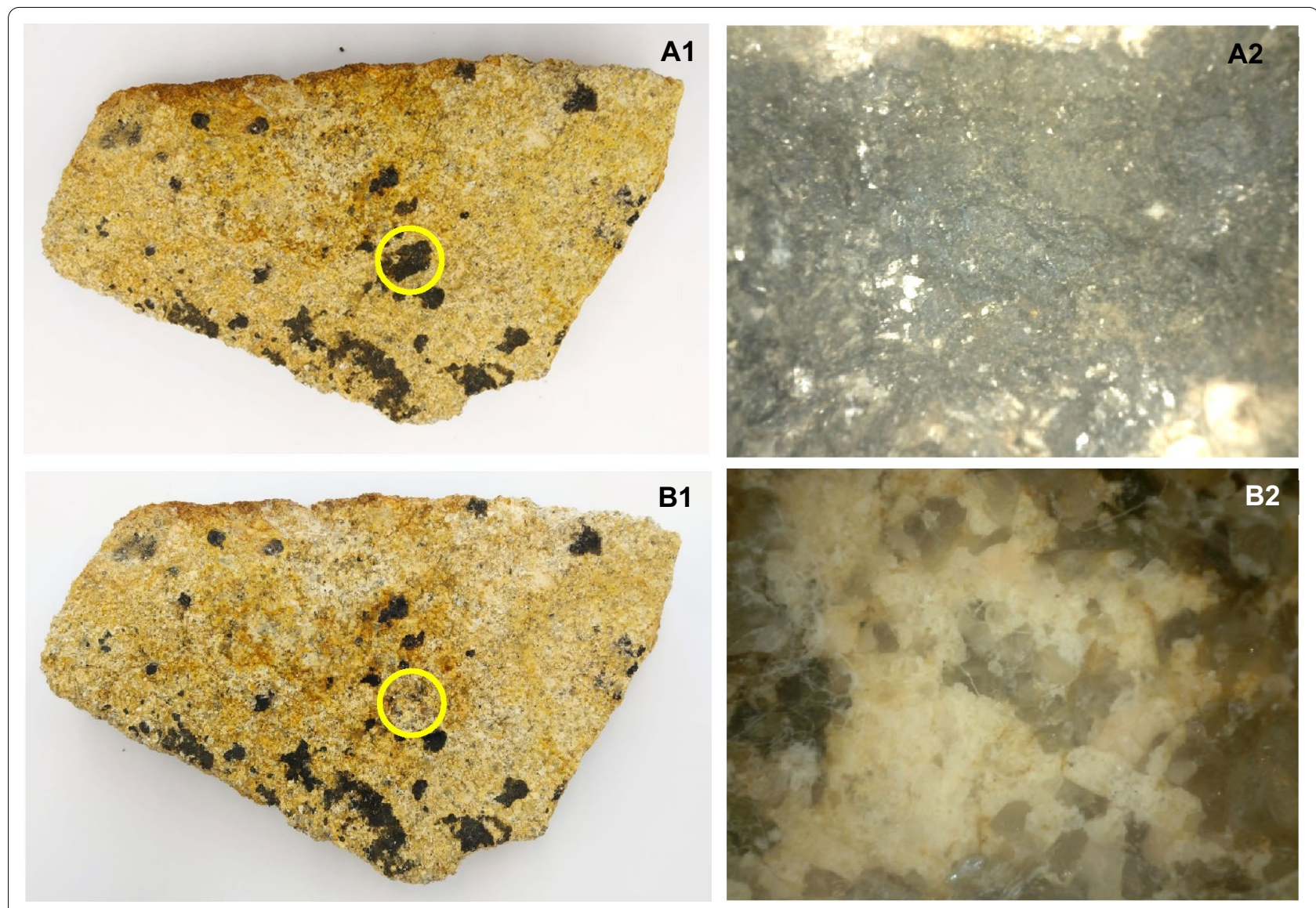

Fig. $\mathbf{3}$ Cleaning assay performed on stained granite sample $\mathbf{I}$. Assays were done inside the labelled yellow marks; $\mathbf{A} \mathbf{1}$ and $\mathbf{A} \mathbf{2}$ are images of stained granite; $\mathbf{B} \mathbf{1}$ and $\mathbf{B} \mathbf{2}$ are images of removed stain. A2 and $\mathbf{B 2}$ images were taken by Dino-lite ( $\times 435$ magnification)

showed $\mathrm{Mn}$ and Fe percentages ranging from 1.87 to $2.97 \%$ and 0.86 to $2.23 \%$, respectively. These percentages originated a $\mathrm{Mn} /$ Fe ratio of $1.22 \pm 0.56$, decreasing $35 \%$ in comparation with $1.64 \pm 0.57$ from Table 1 . The decrease in the $\mathrm{Mn} / \mathrm{Fe}$ ratio seems to influence the changing of CIELAB coordinates because it also led to different $\mathrm{L}^{*}, \mathrm{a}^{*}$ and $b^{*}$ parameters (Table 2). Moreover, granite samples collected at historical quarry appears to present higher Mn percentages $(2.53 \pm 0.58 \%)$ when compared with stained granite at the indicated churches $(1.35 \pm 0.17 \%)$, being perfectly suitable to the proposed cleaning study.

As can be seen in the granite samples I, II and III (Fig. 3 and Additional file 1: Fig. SI5), the cleaning gel effectively removed the black stains within the yellow circles. The images captured by Dino-lite before and after the cleaning procedure, substantiate that these $\mathrm{Mn}$ and $\mathrm{Fe}$ oxides are overlapped at the granite surface, similar to a patina, and the cleaning cycles repetition, where the gel is applied and after removed, is directly associated to the

Table 2 Iron and Manganese percentage of stained granite samples and CIELAB color coordinates

\begin{tabular}{|c|c|c|c|c|c|c|}
\hline \multirow[t]{2}{*}{ Granite sample } & \multicolumn{3}{|c|}{ Elemental analysis } & \multicolumn{3}{|c|}{ CIELAB coordinates } \\
\hline & $\mathrm{Fe}(\%)$ & $M n(\%)$ & $\mathrm{Mn} / \mathrm{Fe}$ & $\mathrm{L}^{*}$ & $a^{*}$ & $\mathbf{b}^{*}$ \\
\hline । & $1.68 \pm 0.09$ & $2.97 \pm 0.24$ & 1.77 & $27.29 \pm 0.40$ & $3.42 \pm 0.18$ & $9.74 \pm 0.32$ \\
\hline$\|$ & $2.23 \pm 0.02$ & $2.76 \pm 0.09$ & 1.24 & $38.69 \pm 0.03$ & $3.50 \pm 0.01$ & $6.74 \pm 0.01$ \\
\hline ॥ा & $0.86 \pm 0.04$ & $1.87 \pm 0.31$ & 0.65 & $38.27 \pm 0.30$ & $3.28 \pm 0.19$ & $9.55 \pm 0.40$ \\
\hline
\end{tabular}

$L^{*}$ lightness, $a^{*}$ red/green value, $b^{*}$ yellow/blue value 
thickness of these superimposed Mn and Fe oxides. Due to the abrasive effect of cotton swabs, is also observed some remaining cotton fibres on the cleaned area (Fig. 3B2).

\section{In situ application on stained granite churches}

$\mathrm{Mn}$-stains characterized in "Characterization of blackblue stains in Vila Real churches (north of Portugal)" section were also submitted to cleaning assays. The areas where the gel was applied are labelled in Additional file 1: Fig. SI1 with dashed yellow circles. As expected, the green gel showed its cleaning efficiency by removing effectively black-blue stains on granite, within the yellow marks, at the three churches (Fig. 4 and Additional file 1: Fig. SI6). Following the same procedure adapted from granite samples, the cleaning cycles were repeated until full stain removal, with reference to the thickness of the patinas that seem to differ. The patina porosity and gel viscosity are factors that influence the penetration depth of the gel. The dissolution/reduction processes promoted by phosphoric acid and thiourea dioxide are enabled on thin layers of manganese oxide. Thus, it is estimated that the number of cleaning cycles is proportional to the porosity and thickness of the patina.

\section{Application on stained Leclanché cells}

Nowadays, Leclanché cells are being used as museum artifacts due to its relevance in the electrochemistry history. ISEP's Museum provided two Mn-stained glass jar cells by (Fig. 5) to test the green gel efficiency, intending to recover the materials originality.

RGB parameters taken at 1-8 and I-IV points are represented in Table 3. The colorimetric methodology to reveal the cleaning gel efficiency is based on a formula used to calculate the magnitude of a vector $(|v|)$ with two points (paper sheet coordinates as reference), exemplified by the following formula (2):

$$
|v|_{1}=\left(\left(R_{I}-R_{1}\right)^{2}+\left(G_{I}-G_{1}\right)^{2}+\left(B_{I}-B_{1}\right)^{2}\right)^{1 / 2} .
$$
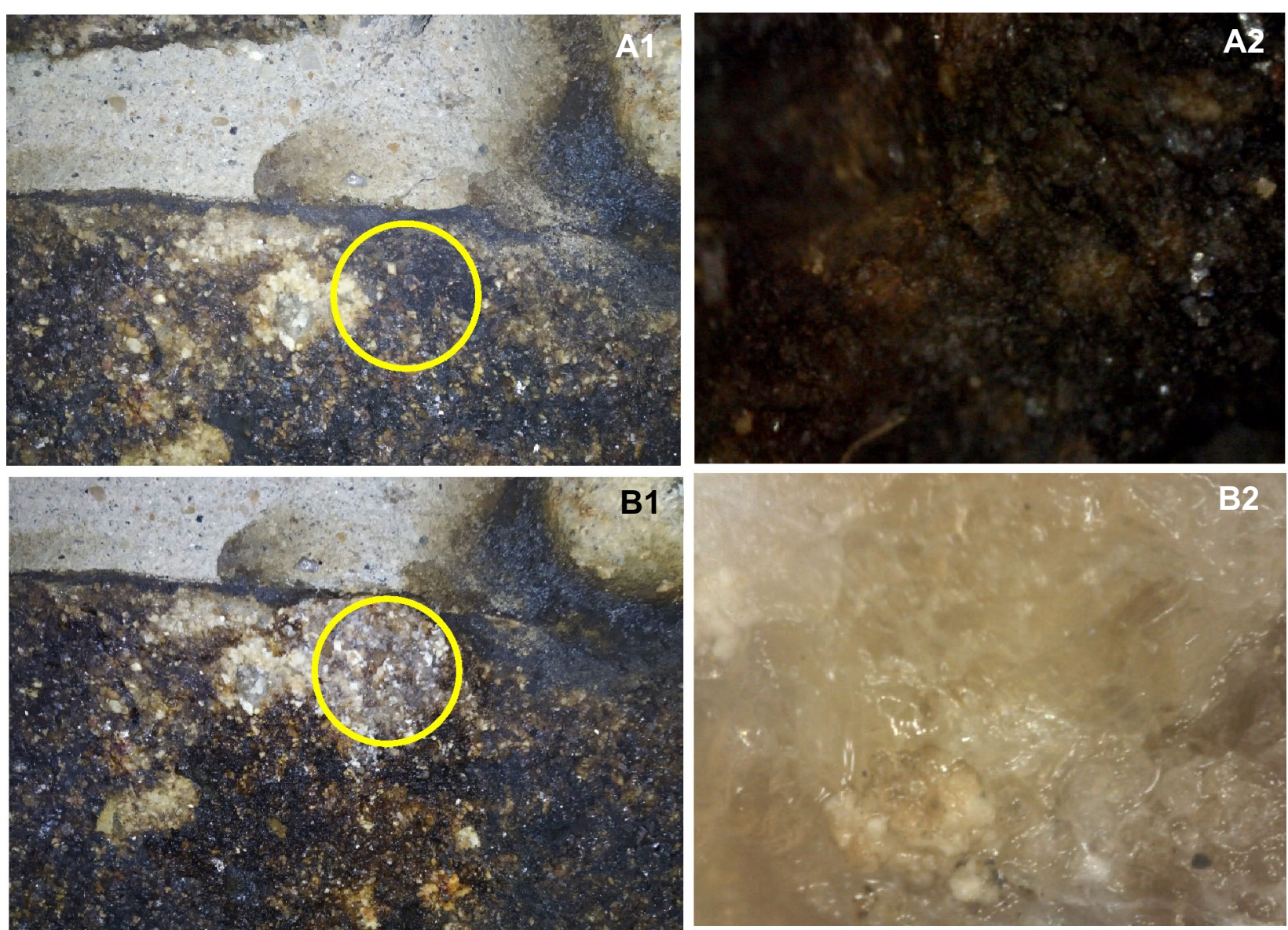

Fig. 4 Cleaning assay performed on stained granite at St. Tiago church. Assays were done inside the labelled yellow marks; $\mathbf{A} \mathbf{1}$ and $\mathbf{A} \mathbf{2}$ are images of stained granite; $\mathbf{B} \mathbf{1}$ and $\mathbf{B} \mathbf{2}$ are images of removed stain. $\mathbf{A} \mathbf{2}$ and $\mathbf{B} \mathbf{2}$ images were taken by Dino-lite ( $\times 435$ magnification) 

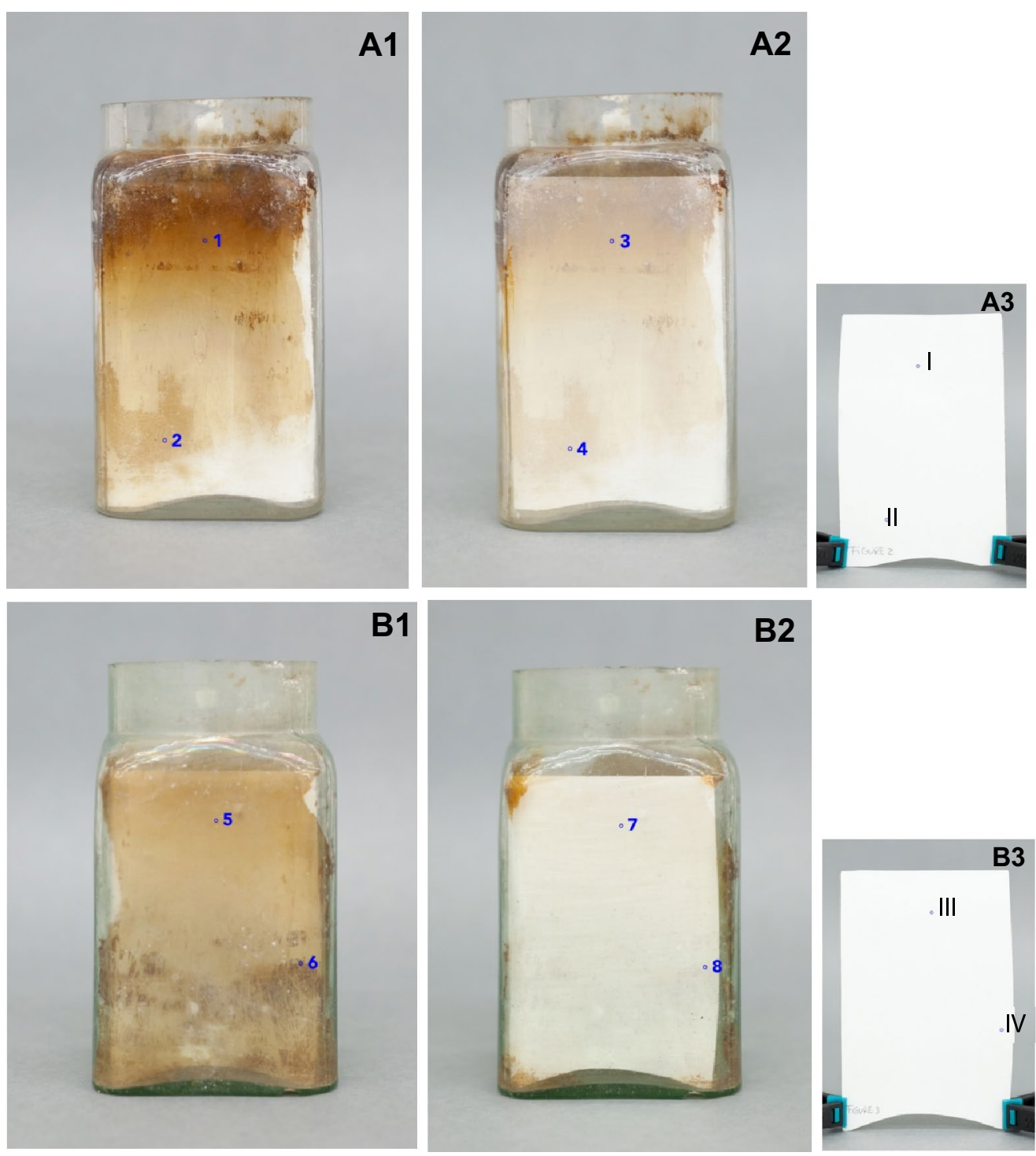

Fig. 5 Two Leclanché cells where the left image is before cleaning (A1 and B1) and the right image is after cleaning (A2 and B2). A3 and B3 are the paper sheets used inside the glass jar

The points 1,$3 ; 2,4 ; 5,7$ and 6,8 are compared with paper sheet RGB coordinates in which the points are I, II, III and IV, respectively. A high $|v|$ indicates a more stained glass, in reverse, a low $|v|$ suggests a more cleaned glass. The same logic is followed by the ratio $|v|_{a c} /|v|_{b c}$, where a low ratio value is indicative of a high cleaning efficiency. Considering the thickness of the glass and the inclination of the light, the results show, in general, an effective cleaning activity of the chitosan: TD gel on glass substrates stained with manganese oxide as shown by the data presented in Table 3. It is also the first time such a green cleaning methodology is discussed for these objects, since the conservation of scientific artifacts is a still underdeveloped field.

\section{Conclusions}

This article presents a safer and innovative cleaning product applied to Mn-rich black-blue stains.

The application of a cleaning product in gel mode offers advantages regarding the evaporation rate and the capillary product penetration. The proposed chitosan: TD cleaning gel showed a acceptable cleaning efficiency on $\mathrm{Mn}$-stained granite and glass. Even more, it fulfils the 
Table 3 RGB data before (1, 2, 5 and 6) and after (3, 4, 7 and 8) the cleaning assay

\begin{tabular}{llllll}
\hline POINTS & $\mathbf{R}$ & $\mathbf{G}$ & $\mathbf{B}$ & $\mathbf{|} \mid$ & $|\mathbf{u}|_{\mathbf{a c}} /\left.\mathbf{u}\right|_{\mathbf{b c}}$ \\
\hline 1 & 150 & 89 & 26 & 292 & 0.40 \\
3 & 209 & 185 & 159 & 117 & \\
$I$ & 249 & 249 & 249 & & \\
2 & 209 & 173 & 124 & 146 & 0.42 \\
4 & 229 & 216 & 194 & 62 & \\
$\|$ & 246 & 246 & 245 & & \\
5 & 195 & 162 & 110 & 171 & 0.26 \\
7 & 233 & 227 & 212 & 44 & \\
III & 248 & 248 & 248 & & \\
6 & 133 & 99 & 70 & 256 & 0.28 \\
8 & 211 & 209 & 195 & 72 & \\
IV & 246 & 247 & 245 & & \\
\hline
\end{tabular}

$\mathrm{R}=$ red, $\mathrm{G}=$ green, $\mathrm{B}=$ blue, $|\mathrm{U}|_{\mathrm{ac}}=$ magnitude of a vector after cleaning and $|\mathrm{u}|_{\mathrm{bc}}=$ magnitude of a vector before cleaning

need for developing greener conservation and restauration methodologies and can be considered a safer and green gel for cleaning Mn-rich stains on cultural artifacts.

\section{Abbreviations}

TD: Thiourea dioxide; HH: Hydroxylamine hydrochloride; HSA: Hydroxymethanesulfinic acid; CIE: International Commission on Illumination; FTIR: Fouriertransform infrared spectroscopy; PXRF: Portable X-ray fluorescence; XPS: X-ray Photoelectron Spectroscopy; BE: Binding energy; AAS: Atomic Absorption Spectroscopy.

\section{Supplementary Information}

The online version contains supplementary material available at https://doi. org/10.1186/s40494-021-00632-y.

Additional file 1. Additional figures and tables.

\section{Acknowledgements}

The authors are grateful to Dr. Jaime Neto from Design and Multimedia Office at ISEP for its support in the RGB data acquisition.

\section{Authors' contributions}

$\mathrm{BC}$ and $\mathrm{GC}$ designed this study and performed the laboratory work. DL collected granite samples. BC, AM, DL, JA and MA accomplished analytical techniques. $B C$ and $A M$ drafted this manuscript. Writing, reviewing, and editing was performed by BC and PM. Reviewing was also performed by EV and MP. Supervision was performed by PM. All authors read and approved the final manuscript.

\section{Funding}

This work was supported by BIO4MURAL-Biotechnology innovative solutions for the removal of pigmentation and preventive conservation of cultural and historically relevant mural painting through FEDER-Operational Program for Competitiveness and Internationalization [Grant Number POCI-01-0145-FEDER-029157] and National Funds from FCT-Foundation for Science and Technology [Grant Number PTDC/HAR-ARQ/29157/2017]; Alexandra Marco PhD research supported by Foundation for Science and Technology (FCT) through POCH-Operational Human Capital Program, co-participated by the Social European Fund (FSE) and MCTES National
Fund [Grant Number SFRH/BD/125596/2016]; and FCT through the Strategic Projects CITAR (UID/EAT/0622/2016) and CBQF [Grant Number UID/ Multi/50016/2013]. Dr. David M. Freire-Lista is supported by FCT through Stimulus of Scientific Employment, Individual Support 2017 [Grant Number CEECIND/03568/2017].

Availability of data and materials

All data generated or analysed during this study are included in this published article [and its additional files].

\section{Declarations}

\section{Competing interests}

The authors declare that they have no competing interests.

\section{Author details}

${ }^{1}$ Research Centre for Science and Technology of the Arts, Universidade Católica Portuguesa, Porto, Portugal. ${ }^{2}$ Centre for Biotechnology and Fine Chemistry, Universidade Católica Portuguesa, Porto, Portugal. ${ }^{3}$ Museu do Instituto Superior de Engenharia do Porto- Instituto Politécnico do Porto, Porto, Portugal. ${ }^{4}$ Universidade de Trás-os-Montes e Alto Douro, Vila Real, Portugal. ${ }^{5}$ Centro de Geociências. Universidade de Coimbra, Coimbra, Portugal. ${ }^{6}$ Departamento de Química Inorgánica, Universidad de Alicante, Alicante, Spain.

${ }^{7}$ Departamento de Química Inorgánica, Universidad de Málaga, Málaga, Spain.

Received: 3 August 2021 Accepted: 23 November 2021

Published online: 16 December 2021

\section{References}

1. Casanova Municchia A, Bartoli F, Bernardini S, Caneva G, Della-Ventura G, Ricci M, Boun Suy T, Sodo T. Characterization of an unusual black patina on the Neang Khmau temple (archaeological Khmer area, Cambodia): a multidisciplinary approach. J Raman Spectrosc. 2016;47(12):1467-72. https://doi.org/10.1002/jrs.4969.

2. Macholdt DS, et al. Black manganese-rich crusts on a Gothic cathedral. Atmos Environ. 2017;171:205-20. https://doi.org/10.1016/j.atmosenv. 2017.10.022.

3. Vicenzi Z, Grissom E, Livingston C, Weldon-Yochim R. "Rock varnish on architectural stone: microscopy and analysis of nanoscale manganese oxide deposits on the Smithsonian Castle, Washington, DC. Herit Sci. 2016;4(1):26. https://doi.org/10.1186/s40494-016-0093-2.

4. Miller AZ, Dionísio A, Sequeira-Braga MA, Hernández-Mariné M, Afonso $M J$, et al. Biogenic Mn oxide minerals coating in a subsurface granite environment. Chem Geol. 2012;322:181-91. https://doi.org/10.1016/j. chemgeo.2012.07.005.

5. Saiz-Jimenez M, Miller C, Martin-Sanchez A, Hernandez-Marine P. Uncovering the origin of the black stains in Lascaux Cave in France. Environ Microbiol. 2012;14(12):3220-31. https://doi.org/10.1111/1462-2920. 12008.

6. Frierdich AJ, Hasenmueller EA, Catalano JG. Composition and structure of nanocrystalline Fe and Mn oxide cave deposits: Implications for trace element mobility in karst systems. Chem Geol. 2011;284(1-2):82-96. https:// doi.org/10.1016/j.chemgeo.2011.02.009.

7. Macholdt DS, et al. Characterization and differentiation of rock varnish types from different environments by microanalytical techniques. Chem Geol. 2017;459:91-118. https://doi.org/10.1016/j.chemgeo.2017.04.009.

8. Dorn RI, Krinsley DH, Langworthy KA, Ditto J, Thompson TJ. The influence of mineral detritus on rock varnish formation. Aeolian Res. 2013;10:61-76. https://doi.org/10.1016/j.aeolia.2013.04.005.

9. Goldsmith Y, Stein M, Enzel Y. From dust to varnish: Geochemical constraints on rock varnish formation in the Negev Desert, Israel. Geochim Cosmochim Acta. 2014;126:97-111. https://doi.org/10.1016/j.gca.2013.10. 040.

10. Uchida S, Watanabe E, Osawa R. Precipitation of manganese oxides on the surface of construction materials in the Khmer temples, Cambodia. Herit Sci. 2016;4(1):16. https://doi.org/10.1186/s40494-016-0086-1. 
11. Huang $\mathrm{H}$, Zhang J. Redox reactions of iron and manganese oxides in complex systems. Front Environ Sci Eng. 2020;14:76. https://doi.org/10. 1007/s11783-020-1255-8.

12. Tebo S, Bargar B, Clement J, Dick B, Murray G, Parker K, Verity D, Webb R. Biogenic manganese oxides: properties and mechanisms of formation. Annu Rev Earth Planet Sci. 2004;32(1):287-328. https://doi.org/10.1146/ annurev.earth.32.101802.120213.

13. Sunda D, Kieber W. Oxidation of humic substances by manganese oxides yields low-molecular-weight organic substrates. Nature. 1994;367(6458):62-4. https://doi.org/10.1038/367062a0.

14. Spiro BM, Bargar TG, Sposito JR, Tebo G. Bacteriogenic manganese oxides. Acc Chem Res. 2009;43(1):2-9. https://doi.org/10.1021/ar800232a.

15. Piazza N, Ciancio-Casalini A, Pacini L, Sanguinetti VA, Ottado G, Gottig J. Environmental bacteria involved in manganese(II) oxidation and removal from groundwater. Front Microbiol. 2019;10:1-13. https://doi.org/10. 3389/fmicb.2019.00119.

16. Martínez-Ruiz EB, Cooper M, Fastner J, Szewzyk U. Manganese-oxidizing bacteria isolated from natural and technical systems remove cylindrospermopsin. Chemosphere. 2020;238: 124625. https://doi.org/10.1016/j. chemosphere.2019.124625.

17. Dakal S, Cameotra T. Microbially induced deterioration of architectural heritages: routes and mechanisms involved. Environ Sci Eur. 2012;24(1):36. https://doi.org/10.1186/2190-4715-24-36.

18. Zhou $\mathrm{C}, \mathrm{Fu} \mathrm{H}$. Manganese-oxidizing microbes and biogenic manganese oxides: characterization, $\mathrm{Mn}$ (II) oxidation mechanism and environmental relevance. Rev Environ Sci Bio/Technol. 2020;19(3):489-507. https://doi. org/10.1007/s11157-020-09541-1.

19. Tebo BM, Johnson HA, McCarthy JK, Templeton AS. Geomicrobiology of manganese(II) oxidation. Trends Microbiol. 2005;13(9):421-8. https://doi. org/10.1016/j.tim.2005.07.009.

20. Caetano J. O Marão E As Oficinas De Pintura Mural Nos Séculos XV E XVI. Lisbon: Aparição; 2001.

21. E. Cavalheiro, A arte dos frescos em Vila Real. João Azevedo Editor, 2004.

22. P. Bessa, "Pintura mural na Igreja de Nossa Senhora de Guadalupe," in Estudos em Homenagem ao Professor Doutor José Marques, Faculdade de Letras da Universidade do Porto, Ed. 2006: 193-215.

23. Jenson A, Singh G, Bhama G, Ratner JK. Hydrogel leclanché cell: construction and characterization. Energies. 2020;13(3):594. https://doi.org/10. 3390/en13030594.

24. Larcin F, Maskell J, Tye W. Leclanché cell investigations. Part II: Zinc potential as a tool for studying intermittent discharge. Electrochim Acta. 1998;44(2-3):191-9. https://doi.org/10.1016/s0013-4686(98)00172-8.

25. Jensen WB. The Leclanché Cell Notes from the Oesper Collections. Cincinnati, 2014. http://hdl.handle.net/2374.UC/731246.

26. Cadeco E, Costa P, Campos BC, Algarra M, Martínez de Yuso MV, Moreira PR, Silva P, Vieira E. The scientific collection of ISEP Museum: Grenet and Leclanché cells. Conserv Património. 2021. https://doi.org/10.14568/ cp2020067.

27. Sahoo J, Kausar P, Lee F, Han J. Facile fabrication of silver nanoparticle embedded $\mathrm{CaCO} 3$ microspheres via microalgae-templated $\mathrm{CO} 2$ biomineralization: application in antimicrobial paint development. RSC Adv. 2014;4(61):32562-9. https://doi.org/10.1039/C4RA03623A.

28. Suda T, Makino A, Higashi T. Extractability of manganese and iron oxides in typical Japanese soils by $0.5 \mathrm{~mol} \mathrm{~L}-1$ hydroxylamine hydrochloride $(\mathrm{pH}$ 1.5). Soil Sci Plant Nutr. 2012;58(6):684-95.

29. Dong Y, Ding L, Huo Y, Zhang W, Lu W, Jin J, Zhao L, Wu Y, Zhang G. A green and facile synthesis for $\mathrm{rGO} / \mathrm{Ag}$ nanocomposites using one-step chemical co-reduction route at ambient temperature and combined first principles theoretical analyze. Ultrason Sonochem. 2019;53:152-63.

30. Mendonça J, Ribeiro P, Abreu J, Guliashvili C, Serra T, Coelho A. Thiourea dioxide as a green and affordable reducing agent for the ARGET ATRP of acrylates, methacrylates, styrene, acrylonitrile, and vinyl chloride. ACS Macro Lett. 2019;8(3):315-9.

31. Yaneva M, Ivanova Z, Nikolova D, Tzanova N. The 21 st century revival of chitosan in service to bio-organic chemistry. Biotechnol Biotechnol Equip. 2020;34(1):221-37. https://doi.org/10.1080/13102818.2020.17313 33.

32. Tobiszewski F, Namieśnik M, Pena-Pereira J. Environmental risk-based ranking of solvents using the combination of a multimedia model and multi-criteria decision analysis. Green Chem. 2017;19(4):1034-42. https:// doi.org/10.1039/c6gc03424a.
33. Taha YM, et al. Cadmium and iron removal from phosphoric acid using commercial resins for purification purpose. Environ Sci Pollut Res. 2020;27:31278-88. https://doi.org/10.1007/s11356-020-09342-7.

\section{Publisher's Note}

Springer Nature remains neutral with regard to jurisdictional claims in published maps and institutional affiliations.

\section{Submit your manuscript to a SpringerOpen ${ }^{\circ}$ journal and benefit from:}

- Convenient online submission

- Rigorous peer review

- Open access: articles freely available online

- High visibility within the field

- Retaining the copyright to your article

Submit your next manuscript at $\boldsymbol{\nabla}$ springeropen.com 